\title{
Tinjauan Kapasitas Dukung Pondasi Bored Pile Menggunakan Formula Statis Dan Elemen Hingga 2D Pada Gedung E Fakultas Teknik Universitas Islam Riau
}

\author{
Review of Capacity to Support the Foundation of Bored Pile Using Static Formulas and \\ Finite 2D Elements in Building E, Faculty of Engineering, Islamic University of Riau
}

\author{
Ramanda Pratama ${ }^{1}$, Anas Puri ${ }^{2}$, Sri Hartati Dewi ${ }^{2}$ \\ ${ }^{1}$ Mahasiswa Program Studi Teknik Sipil, Universitas Islam Riau \\ ${ }^{2}$ Pengajar Program Studi Teknik Sipil, Universitas Islam Riau \\ Pratamaramanda086@gmail.com \\ anaspuri@eng.uir.ac.id \\ srihartatidewi@eng.uir.ac.id
}

\begin{abstract}
Abstrak
Pondasi sebagai dasar bangunan harus mampu memikul seluruh beban bangunan dan beban lainnya, untuk diteruskan sampai kelapisan tanah atau batuan dibawahnya. Pemilihan jenis pondasi salah satunya disebabkan oleh jenis tanah dan jenis struktur atasnya, apakah termasuk konstruksi beban ringan atau beban berat, maka dari itu diperlukan stabilitas tanah itu sendiri agar mempunyai kapasitas dukung yang kuat. Tujuan dari penelitian ini menghitung kapasitas dukung aksial, kapasitas dukung lateral, penurunan, defleksi pondasi bored pile menggunakan metode statis dan elemen hingga 2D, menghitung tegangan geser efektif tanah dengan metode elemen hingga 2D yang kemudian membandingkan dengan beban bekerja dan syarat yang diizinkan.

Dalam menganalisa beban bekerja pada bangunan dihitung menggunakan bantuan software Etabs v.9. Analisa kapasitas dukung pondasi bored pile tunggal menggunakan metode Aoki \& Alancer, Schmertmaan \& Nottingham, Begemaan, dan untuk menghitung kapasitas dukung pondasi bored pile (group) digunakan efisiensi kelompok tiang, sedangkan kapasitas lateral dan defleksi digunakan metode Broms dan penurunan pondasi bored pile tunggal menggunakan metode Dee Beer \& Marten, untuk kelompok tiang menggunakan metode Vesic dan tegangan geser efektif tanah. Dan akan dilakukan analisa menggunakan elemen hingga 2D dengan bantuan software Plaxis 2D v.8.2.

Dari hasil perhitungan dan persentase nilai terbesar kapasitas dukung $\left(Q_{\text {gall }}\right)$ pondasi bored pilegroup As I-39 dan As C-26 pada titik S-1 dengan metode Schmertmaan \& Nottingham sebesar 128\%, metode Begemaan sebesar 139\% dan elemen hingga 2D sebesar $169 \%$ dan dinyatakan pondasi aman terhadap beban yang bekerja pada pile cap, sedangkan metode Aoki \& Alancer sebesar 39\%, dinyatakan tidak aman terhadap beban yang bekerja pada pile cap. Dan kapasitas beban lateralmetode Broms mampu memikul sebesar 167\% dan elemen hingga 2D sebesar 105\% dan dinyatakan aman terhadap beban horizontal yang bekerja. Sedang defleksi pondasi bored pile metode Broms sebesar 2,39 mm, elemen hingga 2D sebesar 3,46 mm, dan penurunan pondasi tunggal dengan metode Dee Beer \& Marten sebesar 9,78 mm, elemen hingga 2D sebesar 36,40 mm dan pondasi bored pile group metode Vesic sebesar 21,87 mm dan elemen hingga 2D sebesar $16,78 \mathrm{~mm}$, dapat dinyatakan defleksi dan penurunan memenuhi syarat yang diizinkan, dan tegangan geser efektif tanah tunggal tanpa interface dan dengan interface tidak memenuhi syarat yang diizinkan
\end{abstract}

Kata Kunci : Bored Pile, Kapasitas Dukung, Penurunan, Defleksi, Plaxis 2D

\begin{abstract}
Foundation, as the building basic must be able to carry the whole building load and other loads to be forwarded to the soil or rock layers underneath. Selection of the foundation type one caused by the type of soil and the type of structure above, whether included construction of a light load or a heavy load, therefore it needed the stability of the land itself in order to have a strong bearing capacity. The purpose of this studies are to calculate the axial bearing capacity, lateral bearing capacity, decreasing, and bored pile foundation deflection using static and $2 D$ finite element method, and calculate effective shear stress of soil with $2 D$ finite element method, then compare with the workload and terms are allowed.
\end{abstract}

In analyzing the workload on buildings, the calculation using ETABS software v.9. Analysis of bearing capacity of single bored pile foundation use Aoki \& Alancer, Schmertmaan \& Nottingham, Begemaan method, and to calculate the bearing capacity of bored pile foundation (group) used the pile groups efficiency, while lateral 
capacity and deflection used Broms method and reduction single bored pile foundation used Dee Beer \& Marten method, for pile group using Vesic method and effective shear stress of soil. And will be analyzed using 2D finite element with Plaxis $2 D$ software v.8.2.

From the calculation and the percentage of the bearing capacity greatest value $\left(Q_{\text {gall }}\right)$, bored pile group foundation As I-39 and As C-26 at S-1 point with Schmertmaan \& Nottingham method amounted to 128\%, Begemaan method amounted to $139 \%$ and the $2 D$ finite element amounted to $169 \%$ and foundation declared safe to the load on the pile cap, whereas Aoki and Alancer method amounted to 39\%, declared unsafe to load on the pile cap. And the lateral load capacity Broms method capable of assuming at $167 \%$ and the 2D finite element about $105 \%$ and declared safe to horizontal workload. Bored pile foundation deflection with Broms method amounted to $2.39 \mathrm{~mm}, 2 \mathrm{D}$ finite element amounted to $3.46 \mathrm{~mm}$, and a decrease in single foundation with Dee Beer \& Marten method amounted to $9.78 \mathrm{~mm}, 2 \mathrm{D}$ finite element amounted to $36.40 \mathrm{~mm}$ and bored pile group foundation Vesic method amounted to $21.87 \mathrm{~mm}$ and $2 \mathrm{D}$ finite element amounted to $16.78 \mathrm{~mm}$, it can be stated that deflection and decrease are eligible permitted, and effective shear stress of single soil with and without interface are ineligible permitted.

Keywords : Bored pile, Bearing capacity, Decrease, Deflection, Plaxis 2D

\section{PENDAHULUAN}

\subsection{Latar Belakang}

Pekerjaan pondasi (struktur bawah) merupakan elemen struktur yang lebih dahulu dilaksanakan. Pembangunan suatu pondasi memberikan efek yang besar pada suatu konstruksi. Secara umum pondasi didefinisikan sebagai bagian terendah dari bangunan yang meneruskan beban bangunan ke tanah atau batuan yang ada di bawahnya (Hardiyatmo, 2002).

Suatu perencanaan pondasi dikatakan benar apabila beban yang diteruskan pondasi ke tanah tidak melampaui kekuatan tanah yang bersangkutan. Apabila kekuatan tanah dilampaui, maka penurunan yang berlebihan dan keruntuhan dari tanah akan terjadi. Kedua hal tersebut akan menyebabkan kerusakan pada kontruksi yang berada diatas pondasi tersebut (Hulu, 2015).

Pondasi sebagai struktur bawah secara umum dapat dibagi dalam 2 (dua) jenis, yaitu pondasi dalam dan pondasi dangkal. Pemilihan jenis pondasi bergantung pada beban yang harus didukung, kondisi tanah, dan biaya pembuatan pondasi yang dibandingkan terhadap biaya struktur atasnya (Hardiyatmo, 2002). Untuk konstruksi beban ringan dan kondisi lapisan tanah yang baik biasanya cukup digunakan jenis pondasi dangkal, sedangkan untuk konstruksi struktur atas yang memiliki beban berat biasanya jenis pondasi dalam yang lebih tepat digunakan. Dalam pembangunannya, diperlukan pondasi sebagai dasar bangunan yang kuat dan kokoh. Hal ini disebabkan karena pondasi berperan penting untuk menopang bangunan di atasnya agar dapat menjamin kestabilan bangunan terhadap berat sendiri, beban-beban bekerja, gaya-gaya luar seperti angin, gempa bumi dan lain sebagainya.

Pada pembangunan Gedung E Fakultas Teknik yang berada di lokasi Universitas Islam Riau dibangun sebanyak 3 lantai dan 1 lantai bassment. Bangunan yang berfungsi sebagai tempat proses pembelajaran mahasiswa dan termasuk jenis bangunan bertingkat tinggi. Jenis pondasi yang digunakan adalah pondasi bored pile dengan panjang $9 \mathrm{~m}$ dengan diameter $40 \mathrm{~cm}$. Pondasi bored pile sering digunakan dalam dunia konstruksi khususnya di kota Pekanbaru, mulai dari konstruksi gedung tinggi sampai bangunan ruko seperti halnya pada pembangunan Gedung E Fakultas Teknik Universitas Islam Riau.

Daya dukung bored pile diperoleh dari penjumlahan kuat dukung ujung (end bearing capacity) yang diperoleh dari tekanan ujung bored pile dan kuat dukung geser atau selimut (friction bearing capacity) yang diperoleh dari daya dukung gesek antara bored pile dan tanah sekelilingnya.

Bored pile berintraksi dengan tanah untuk menghasilkan daya dukung yang mampu memikul dan memberikan keamanan pada struktur atas. Untuk menghasilkan daya dukung 
akurat maka diperlukan suatu penyelidikan tanah akurat juga.

Dari data yang didapatkan, penyelidikan tanah yang dilakukan hanya menggunakan metode statis. Penyelidikan tanah dengan metode statis adalah penyelidikan menggunakan alat uji penetrasi konus (CPT). Penyelidikan uji penetrasi konus bertujuan untuk mengetahui perlawanan penetrasi konus dan hambatan lekat yang merupakan indikasi dari kekuatan daya dukung lapisan tanah dengan menggunakan rumus empiris (Hardiyatmo, 2002).

Berdasarkan data tersebut perhitungan daya dukung bored pile sangat diperlukan untuk mendapatkan perencanaan pondasi yang memenuhi persyaratan. Hal ini yang membuat peneliti ingin melakukan tinjauan kapasitas dukung pondasi bored pile pada Gedung $\mathrm{E}$ Fakultas Teknik Universitas Islam Riau Pekanbaru.

\subsection{Rumusan Masalah}

Berdasarkan uraian pada latar belakang, maka perumusan masalah dapat diuraikan sebagai berikut :

1. Apakah kapasitas dukung dan kapasitas beban lateral pondasi bored pile aman terhadap beban yang bekerja pada pile cap ?

2. Apakah penurunan dan defleksi akibat beban yang bekerja pada pile cap memenuhi syarat yang diizinkan?

3. Apakah tegangan geser efektif tanah memenuhi syarat yang diizinkan?

\subsection{Tujuan Penelitian}

Adapun tujuan yang hendak dicapai dalam penulisan dan pembahasan Tugas Akhir ini adalah sebagai berikut :

1. Menghitung kapasitas dukung dan kapasitas beban lateral pondasi bored pile tunggal dengan metode statis dan metode elemen hingga $2 \mathrm{D}$.

2. Menghitung penurunan dan defleksi pondasi bored pile dengan metode statis dan elemen hingga 2D.

3. Menghitung tegangan geser efektif tanah dengan metode elemen hingga 2D.

\subsection{Manfaat Peneltian}

Manfaat dari penelitian ini adalah sebagai berikut :
1. Bagi penulis, untuk menambah ilmu pengetahuan tentang pondasi bored pile serta mengetahui tata cara perhitungan.

2. Bagi pihak pembaca, sebagai bahan referensi bagi mahasiswa yang sedang dan akan melakukan penelitian yang sama.

\subsection{Batasan Masalah}

Adapun batasan masalah pada permasalahan ini adalah sebagai berikut :

1. Menghitung beban aksial, lateral dan momen menggunakan software Etabs.

2. Menghitung kapasitas dukung menggunakan metode Aoki \& Alancer, metode Schertmann \& Nothinghamm dan metode Begemann.

3. Menghitung kapasitas dukung bored pile tunggal menggunakan MEH 2D analisis aksisimetri dan bored pile kelompok dengan analisis plane strain.

4. Menghitung kapasitas beban lateral dan defleksi bored pile tunggal menggunakan metode Broms dan MEH 2D analisis aksisimetris.

5. Menghitung penurunan segera bored pile tunggal dengan metode Dee Beer \&Marten dan MEH 2D analisis aksisimetri, dan bored pile kelompok dengan metode Vesic dan MEH 2D analisis plane strain.

6. Menghitung tegangan geser efektif tanah menggunakan $\mathrm{MEH} \quad 2 \mathrm{D}$ analisis aksisimetri.

7. Tidak membahas metode pelaksanaan dan rencana anggaran biaya (RAB).

\section{METODE PENELITIAN}

\subsection{Lokasi Penelitian}

Lokasi dari objek yang akan diteliti adalah Gedung E Fakultas Tenik Universitas Islam Riau yang berada di Jalan Kaharuddin Nasution Km 11, Perhentian Marpoyan, Pekanbaru, Riau.Gedung yang berada di kawasan kampus Universitas Islam Riau, direncanakan 3 lantai dan 1 lantai basement. Peta lokasi Gedung E Fakultas Teknik Universitas Islam Riau dapat dilihat pada Gambar 2.1. 


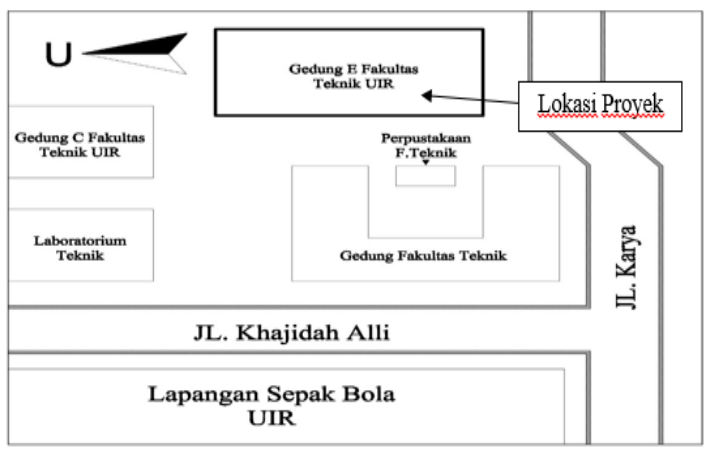

Gambar 2.1 Denah Lokasi Gedung E Fakultas Teknik UIR - Pekanbaru

\subsection{Teknik Pengumpulan Data}

Dalam penelitian terdapat hal penting yang berhubungan dengan data yang diperlukan antara lain :

1. Studi literatur atau studi kepustakaan yaitu studi yang didapat dengan mempelajari atau menganalisa bahan yang sudah ada seperti : buku-buku, jurnal, artikel-artikel. Adapun buku yang diambil dalam penelitian ini diantaranya Buku Teknik Pondasi dan buku - buku yang berhubungan dengan penelitian ini.

2. Data Sekunder yaitu berupa data yang didapatkan secara tidak langsung (didapat dari penelitian lain) atau didapatkan dari kontraktor berupa gambar as build drawing, terutama gambar detail struktur Gedung E Fakultas Teknik Universitas Islam Riau dan data pengujian tanah dengan uji penetrasi konus (CPT).

\subsection{Gambaran Umum Bangunan}

Gambaran umum bangunan menjelaskan data-data struktur bangunan dan lokasi titik uji penetrasi konus (CPT) yang memberikan informasi mengenai bangunan yang dijadikan objek penelitian ini.

\subsubsection{Lokasi Titik Uji Penetrasi Konus (CPT)}

Data-data yang digunakan untuk analisa perhitungan pondasi pada lokasi pembangunan Gedung E Fakultas Tenik Universitas Islam Riau yang terdiri dari 4 (empat) titik uji penetrasi konus (CPT)yaitu (S-1), (S-2), (S-3) dan (S-4) dapat dilihat padaGambar 2.2

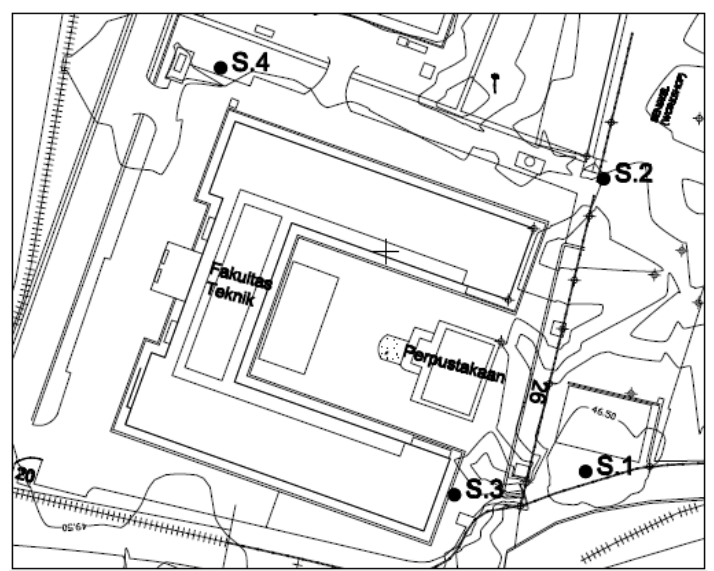

Gambar 2.2 Lokasi titik uji penetrasi konus (CPT)

\subsubsection{Data Teknis Struktur}

1. Nama Bangunan : Gedung E Fakultas Teknik Universitas Islam Riau

2. Tinggi tiap lantai dari lantai dasar :

$\begin{array}{ll}\text { Lantai Dak } & : 13,90 \mathrm{~m} \\ \text { Lantai } 3 & : 10,15 \mathrm{~m} \\ \text { Lantai } 2 & : 6,35 \mathrm{~m} \\ \text { Lantai } 1 & : 2,55 \mathrm{~m} \\ \text { Basement } & : 0,00 \mathrm{~m}\end{array}$

\subsubsection{Data Teknis Pondasi Bored Pile}

Pondasi yang digunakan adalah jenis pondasi tiang bor (bored pile) dengan satu tipe dan dengan panjang tiang sama yakni $9 \mathrm{~m}$. Berikut data yang diperoleh dari kontraktor dengan data sebagai berikut :

1. Panjang tiang bor $: 9 \mathrm{~m}$

2. Diameter tiang bor $: 40 \mathrm{~cm}$

3. Detail pondasi : Lampiran B gambar

4. Titik pondasi tipe P1

a) Titik As I - 39 (Data ETABS)

b) Titik As C-26 (Data ETABS)

Denah titik pondasi yang ditinjau dapat dilihat Gambar 2.3

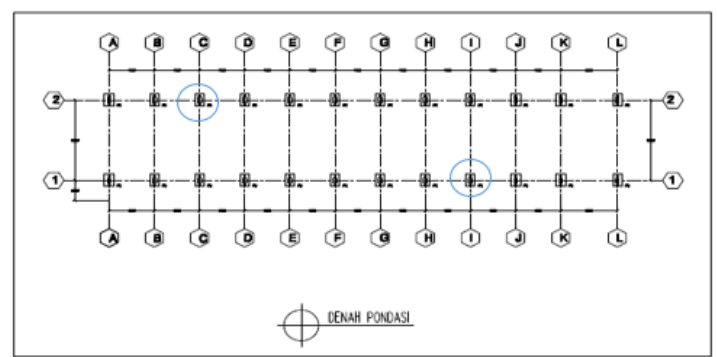

Gambar 2.3 Denah pondasi bored pile 


\subsection{Tahapan Pelaksanaan Penelitian}

Dalam melaksanakan penelitian ini untuk langkah penelitian secara umum dapat dilihat pada Gambar 2.4 dibawah ini.

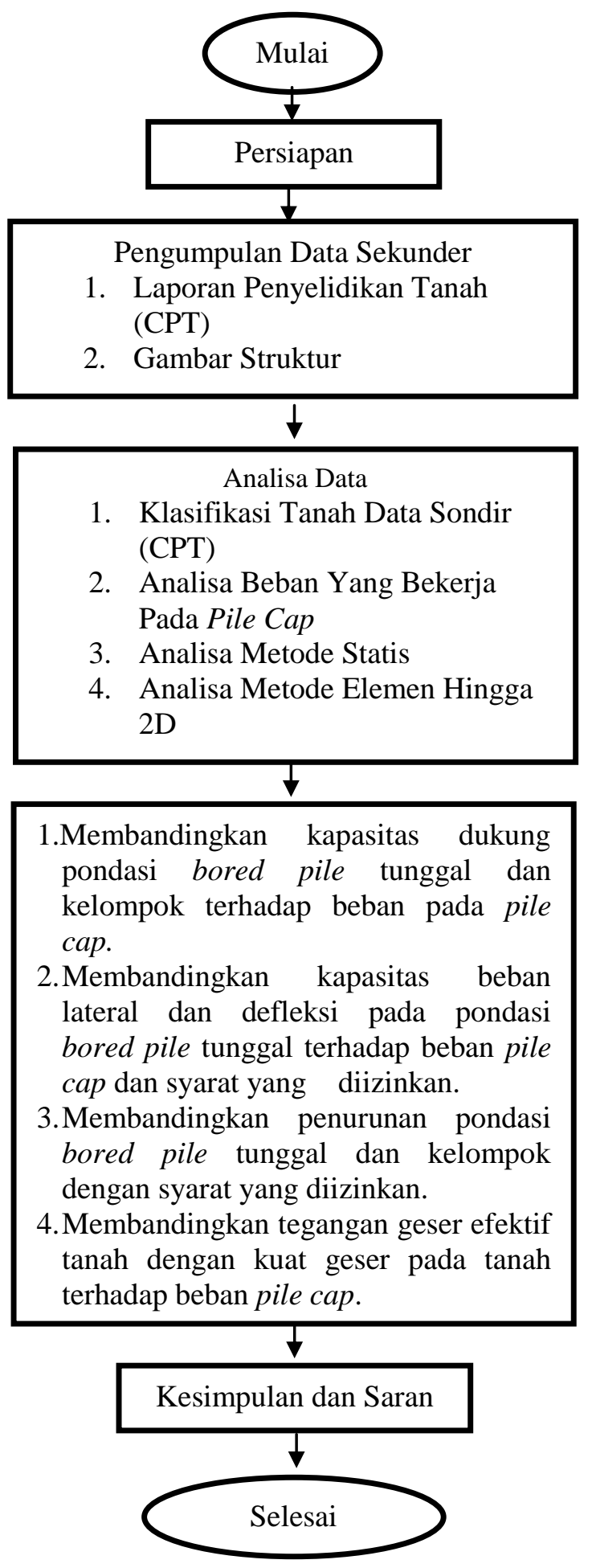

Gambar 2.4 Tahapan pelaksanaan penelitian
2.4.1 Persiapan Dan Pengumpulan Data

1. Tahap persiapan peneliti melakukan beberapa persiapan diantaranya pengurusan surat untuk pengambilan data yang ditunjukan kepada Wakil Rektor IV Univeristas Islam Riau, mencari buku referensi tentang pondasi, serta membaca beberapa Tugas Akhir dari peneliti terdahulu sebagai gambaran dari penelitian tentang pondasi bored pile.

2. Pengumpulan data ini didapat dari konsultan perencanaan struktur Gedung E Fakultas Teknik Universitas Islam Riau. Data yang didapat antara lain :

a) Data penyelidikan tanah berupa data uji penetrasi konus (CPT).

b) Gambar struktur meliputi denah dan detail pondasi.

\subsubsection{Analisa Data}

Apabila data-data yang diperlukan sudah lengkap, maka dilakukan analisa sebagai berikut :

1. Analisa klasifikasi tanah

Mengklasifikasikan jenis tanah berdasarkan data hasil penyondiran dengan menghitung rasio gesekan $\left(f_{r}\right)$ (menurut Robertson dan Campanella, 1983) yang kemudian di plot kebagan klasifikasi tanah.

2. Analisa pembebanan

Analisa beban maksimal yang bekerja pada pile cap yang disalurkan ke pondasi bored pile menggunakan ETABS. Beban - beban yang meliputi beban mati, beban hidup, gempa dan angin berdasarkan Pedoman Perencanaan Pembebanan Untuk Rumah dan Gedung, (1987)(SKBI).

3. Analisa metode statis

a) Analisa kapasitas dukung pondasi bored pile tunggal menggunakan metode Aoki \&Alancer, metode Schmertmann \&Nothinghamm, metode Begemann dan kelompok menggunakan Formula Converse-Laberre.

b) Analisa kapasitas beban lateral dan defleksi pondasi bored pile tunggal menggunakan metode Broms.

c) Analisa penurunan pondasi bored pile tunggal menggunakan metode Dee Beer dan Marten dan kelompok menggunakan metode Vesic. 


\section{Analisa MEH 2D}

a) Analisa kapasitas dukung pondasi bored pile tunggal menggunakan analisis aksisimetri dan kelompok analisis plane strain.

b) Analisa kapasitas beban lateral dan defleksi pondasi bored pile tunggal menggunakan analisis aksisimetri.

c) Analisa penurunan pondasi bored pile tunggal menggunakan analisis aksisimetri dan kelompok analisis plane strain.

d) Analisa tegangan geser efektif tanah menggunakan analisis aksisimetri.

\subsubsection{Hasil Dan Pembahasan}

Setelah data penelitian dianalisa dengan menggunakan beberapa metode analisa pondasi bored pile, maka akan didapatkan hasil perhitungan yang berguna untuk dibahas dan diambil kesimpulan dari hasil perhitungan tersebut. Dalam hasil dan pembahasan dari analisa kapasitas dukung pondasi bored pile tunggal, kelompok dan kapasitas lateral pondasi bored pile tunggal akan dibandingkan dengan beban yang bekerja pada pilecap. Dan juga hasil dari penurunan pondasi bored pile tunggal, kelompok dan defleksi pondasi bored pile tunggal akibat beban yang bekerja pada pile cap, apakah masih dalam syarat yang diizinkan dan hasil analisa tegangan geser efektif tanah dibandingkan dengan kuat geser pada tanah, apakah memenuhi syarat yang diizinkan.

\subsubsection{Kesimpulan Dan Saran}

Dari pembahasan yang telah dilakukan maka diambil kesimpulan dari penelitian ini apakah kapasitas dukung pondasi bored pile aman atau tidak menerima beban yang bekerja pada pile cap dan apakah deformasi, tegangan efektif tanah pada pondasi memenuhi syarat yang diizinkan. Dan memberikan saran untuk penelitian selanjutnya.

\subsection{Cara Analisis}

Cara analisis bertujuan untuk menjelaskan lebih detail lagi dalam penelitian ini seperti yang dirangkum pada bagian alir penelitian di atas. Adapun cara-cara menganalisis tersebut adalah sebagai berikut :

1. Penentuan klasfikasi jenis tanah menggunakan metode Robetson dan Campanella, (1983).

2. Perhitungan pembebanan data yang dipakai dalam pembebanan adalah Pedoman Perencanaan Pembebanan Untuk Rumah dan Gedung, (1987)(SKBI), perhitungan beban gempa yang bekerja menggunakan metode analisis respons spektrum dengan dibantu software ETABS.

3. Perhitungan kapasitas dukung pondasi bored pile tunggal dari hasil uji penetrasi konus (CPT) dengan menggunakan metode Aoki De Alancer, metode Schmertmann \& Nothinghamm, metode Begemann dan metode elemen hingga 2D analisis aksisimetri.

4. Perhitungan kapasitas dukung pondasi bored pile kelompok dapat menggunakan persamaan - persamaan effesiensi kelompok tiang dari Converse-Labarre Formula dan metode elemen hingga 2D analisis plane strain.

5. Perhitungan kapasitas lateral dan defleksi dengan menggunakan metode Broms dan metode elemen hingga 2D analisis aksisimetri.

6. Perhitungan penurunan segera pondasi bored pile tunggal menggunakan metodeDe Beer dan Marten dan metode elemen hingga 2D analisis aksisimetri.

7. Perhitungan penurunan pondasi bored pile kelompok menggunakan metodeVesic dan metode elemen hingga 2D analisis plane strain.

8. Perhitungan tegangan geser efektif tanah menggunakan metode elemen hingga 2D analisis aksisimetri.

9. Dalam analisa dan pembahasan diberikan data berbentuk tabel dan grafik. 


\section{HASIL DAN PEMBAHASAN}

\subsection{Deskripsi Umum}

Struktur pondasi pada Gedung E Fakultas Teknik Universitas Islam Riau menggunakan pondasi bored pile tiang kelompok (group) dengan 2 tiang bor dan berdiameter $40 \mathrm{~cm}$, mutu beton yang digunakan pada struktur pondasi bored pile $\mathrm{K}-250\left(f c^{\prime}=21 \mathrm{Mpa}\right)$ dan penyelidikan tanah yang dipakai menggunakan data hasil uji penetrasi konus $(C P T)$. Penelitian ini dilakukan untuk menentukan kapasitas dukung aksial dan kapasitas beban lateral, penurunan, defleksi dan tegangan geser efektif tanah yang terjadi akibat beban kerja yang terjadi pada pondasi yang mengalami beban maksimal, dan menghitung beban yang bekerja dengan menggunakan program ETABS berdasarkan data gambar struktur dan arsitektur.

\subsection{Hasil Analisa Kapasitas Dukung} Pondasi Bored Pile Tunggal

Tabel 3.1 Kapasitas Dukung Pondasi Bored Pile Tunggal As I - 39 Dan As C - 26 Metode Statis

\begin{tabular}{|l|l|c|}
\hline \multicolumn{3}{|c|}{ Kapasitas Dukung Izin Pondasi $\left(Q_{\text {all }}\right)(\mathrm{kN})$} \\
\hline $\begin{array}{l}\text { Aoki \& } \\
\text { Alancer }\end{array}$ & $\begin{array}{l}\text { Schmertmann \& } \\
\text { Nottingham }\end{array}$ & Begemann \\
\hline 278,03 & 906,12 & 985,67 \\
\hline
\end{tabular}

Tabel 3.2 Kapasitas Dukung Pondasi Bored Pile Tunggal As I - 39 Dan As C - $26 \mathrm{MEH}$ 2D

\begin{tabular}{|c|c|c|}
\hline \multirow{2}{*}{$\begin{array}{c}\text { Titik } \\
\text { Pondasi }\end{array}$} & $\begin{array}{c}\text { Kapasitas Dukung Izin Pondasi } \\
\left(Q_{\text {all }}\right)(\mathrm{kN})\end{array}$ \\
\cline { 2 - 3 } & \multicolumn{2}{|c|}{ MEH 2D } \\
\cline { 2 - 3 } & $\begin{array}{c}\text { Tanpa } \\
\text { interface }\end{array}$ & $\begin{array}{c}\text { Menggunakan } \\
\text { interface }\end{array}$ \\
\hline As I - 39 & 670,32 & 522,27 \\
\hline As C - 26 & 497,69 & 383,15 \\
\hline
\end{tabular}

Berdasarkan hasil Tabel 3.1 dan Tabel 3.2 maka dapat disajikan secara grafik hasil analisa kapasitas dukung $\left(Q_{\text {all }}\right)$ pondasi bored pile tunggal pada As I - 39 dapat dilihat pada Gambar 2.5 sebagai berikut :

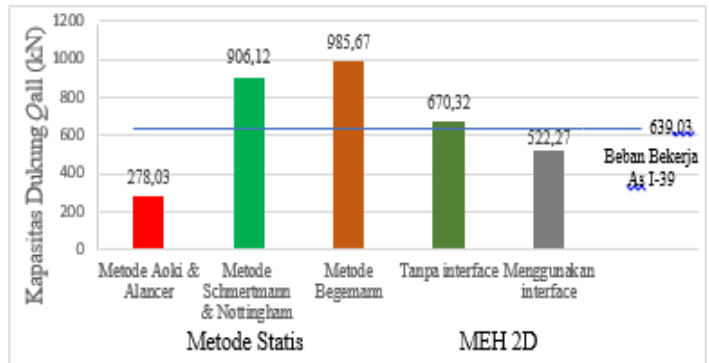

Gambar 2.5 Perbandingan kapasitas dukung $\left(Q_{\text {all }}\right)$ pondasi bored pile tunggal As

I - 39 antara metode statis dan metode elemen hingga $2 \mathrm{D}$

Berdasarkan hasil Tabel 3.1 dan Tabel 3.2 maka dapat disajikan secara grafik hasil analisa kapasitas dukung $\left(Q_{\text {all }}\right)$ pondasi bored pile tunggal pada As C - 26 dapat dilihat pada Gambar 2.6 sebagai berikut :

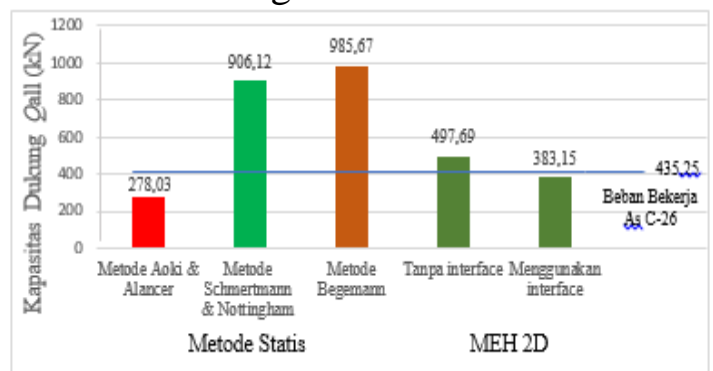

Gambar 2.6 Perbandingan kapasitas dukung $\left(Q_{\text {all }}\right)$ pondasi bored pile tunggal As C - 26 antara metode statis dan metode elemen hingga 2D

3.4 Hasil Analisa Kapasitas Dukung Pondasi Bored Pile Kelompok (Group)

Tabel 3.3 Kapasitas Dukung Pondasi Bored Pile (Group) As I - 39 Dan As C - 26

Metode Statis

\begin{tabular}{|c|c|c|}
\hline \multicolumn{4}{|c|}{ Kapasitas Dukung Izin Pondasi $\left(Q_{\text {gall }}\right)(\mathrm{kN})$} \\
\hline $\begin{array}{c}\text { Aoki \& } \\
\text { Alancer }\end{array}$ & $\begin{array}{c}\text { Schmertmann \& } \\
\text { Nottingham }\end{array}$ & Begemann \\
\hline 500,45 & 1631,02 & 1774,21 \\
\hline
\end{tabular}


Tabel 3.4 Kapasitas Dukung Pondasi Bored Pile (Group) As I - 39 Dan As C - 26 MEH 2D

\begin{tabular}{|c|c|c|}
\hline \multirow{2}{*}{$\begin{array}{c}\text { Titik } \\
\text { Pondasi }\end{array}$} & \multicolumn{2}{|c|}{$\begin{array}{c}\text { Kapasitas Dukung Izin Pondasi } \\
\left(Q_{\text {gall }}\right)(\mathrm{kN})\end{array}$} \\
\cline { 2 - 3 } & \multicolumn{2}{|c|}{ MEH 2D } \\
\cline { 2 - 3 } & $\begin{array}{c}\text { Tanpa } \\
\text { interface }\end{array}$ & $\begin{array}{c}\text { Menggunakan } \\
\text { interface }\end{array}$ \\
\hline As I - 39 & 2163,24 & 2073,61 \\
\hline As C - 26 & 1804,65 & 1737,90 \\
\hline
\end{tabular}

Berdasarkan hasil Tabel 3.3 dan Tabel 3.4 maka dapat disajikan secara grafik hasil analisa kapasitas dukung $\left(Q_{\text {gall }}\right)$ pondasi bored pile(Group) pada As I - 39 dapat dilihat pada Gambar 2.7 sebagai berikut :

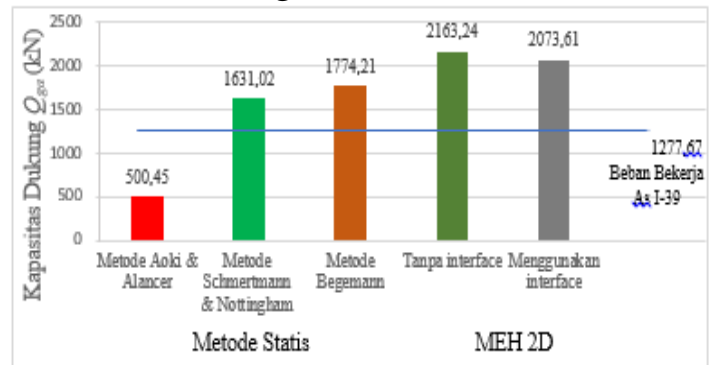

Gambar 2.7Perbandingan kapasitas dukung $\left(Q_{\text {gall }}\right)$ pondasi bored pile(Group) As I-39 antara metode statis dan metode elemen hingga $2 \mathrm{D}$

Berdasarkan hasil Tabel 3.3 dan Tabel 3.4 maka dapat disajikan secara grafik hasil analisa kapasitas dukung $\left(Q_{\text {gall }}\right)$ pondasi bored pile (Group) pada As C - 26 dapat dilihat pada Gambar 2.8 sebagai berikut :

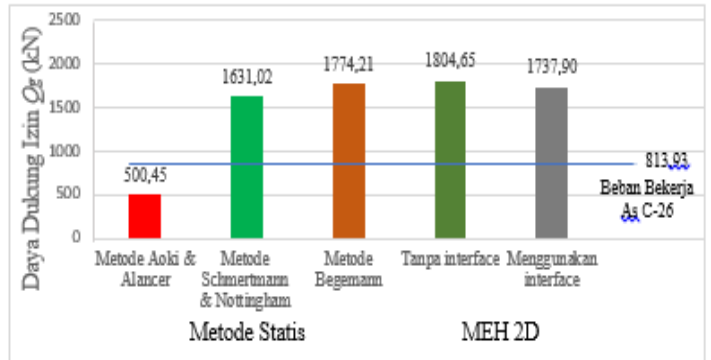

Gambar 2.8 Perbandingan kapasitas dukung $\left(Q_{\text {gall }}\right)$ pondasi bored pile(Group)As C - 26 antara metode statis dan metode elemen hingga $2 \mathrm{D}$
3.5 Hasil Analisa Kapasitas Beban Lateral Pondasi Bored Pile Tunggal

Tabel 3.5 Kapasitas beban lateral pondasi bored pile tunggal

\begin{tabular}{|c|c|c|c|}
\hline \multirow{2}{*}{$\begin{array}{c}\text { Titik } \\
\text { Pondasi }\end{array}$} & \multicolumn{3}{|c|}{ Kapasitas Dukung Izin Pondasi } \\
& \multirow{2}{*}{$\begin{array}{c}\text { Metode } \\
\text { Broms }\end{array}$} & \multicolumn{2}{|c|}{ MEH 2D } \\
\cline { 3 - 4 } & $\begin{array}{c}\text { Tanpa } \\
\text { interface }\end{array}$ & $\begin{array}{c}\text { Dengan } \\
\text { interface }\end{array}$ \\
\hline As I-39 & 66,68 & 2163,24 & 2073,61 \\
\hline As C-26 & 51,54 & 1804,65 & 1737,90 \\
\hline
\end{tabular}

Berdasarkan hasil Tabel 3.5 maka dapat disajikan secara grafik hasil analisa kapasitas beban lateral $\left(H_{a}\right)$ pondasi bored pile tunggal pada As I - 39 dapat dilihat pada Gambar 2.9 sebagai berikut :

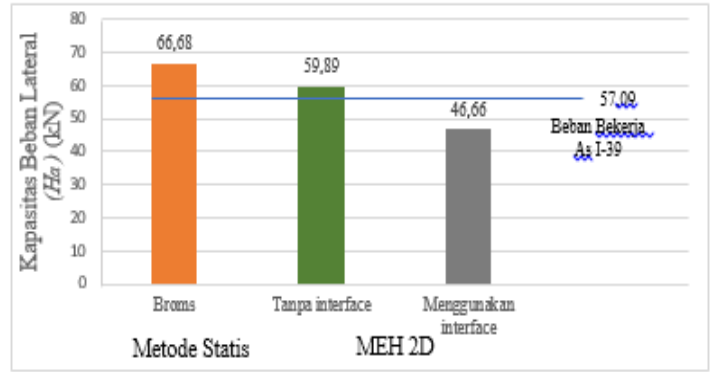

Gambar 2.9 Perbandingan kapasitas beban lateral $\left(H_{a}\right)$ pondasi bored pile As I -39 antara metode Broms dan metode elemen hingga 2D

Berdasarkan hasil Tabel 3.5 maka dapat disajikan secara grafik hasil analisa kapasitas beban lateral $\left(H_{a}\right)$ pondasi bored pile tunggal pada As C - 26 dapat dilihat pada Gambar 2.10 sebagai berikut :

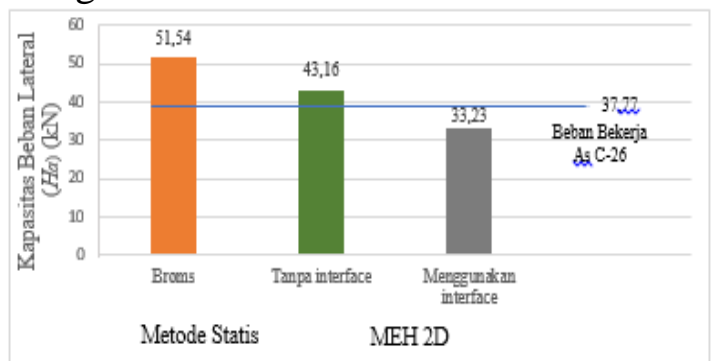

Gambar 2.10 Perbandingan kapasitas beban lateral $\left(H_{a}\right)$ pondasi bored pile As $\mathrm{C}-26$ antara metode Broms dan metode elemen hingga 2D 
3.6 Hasil Analisa Defleksi Pondasi Bored Pile Tunggal

Tabel 3.6 Defleksi pondasi bored pile tunggal

\begin{tabular}{|c|c|c|c|}
\hline \multirow{2}{*}{$\begin{array}{c}\text { Titik } \\
\text { Pondasi }\end{array}$} & \multicolumn{3}{|c|}{$\begin{array}{c}\text { Defleksi } \\
\text { (mm) }\end{array}$} \\
\cline { 2 - 4 } & \multirow{2}{*}{$\begin{array}{c}\text { Metode } \\
\text { Broms }\end{array}$} & $\begin{array}{c}\text { MEH 2D } \\
\text { Tanpa } \\
\text { interface }\end{array}$ & $\begin{array}{c}\text { Dengan } \\
\text { interface }\end{array}$ \\
\hline As I-39 & 2,39 & 2,67 & 3,46 \\
\hline As C-26 & 1,58 & 2,03 & 2,71 \\
\hline
\end{tabular}

Berdasarkan hasil Tabel 3.6 dapat disajikan secara grafik hasil analisa defleksi pondasi bored pile tunggal pada As I - 39 dapat dilihat pada Gambar 2.11 sebagai berikut :

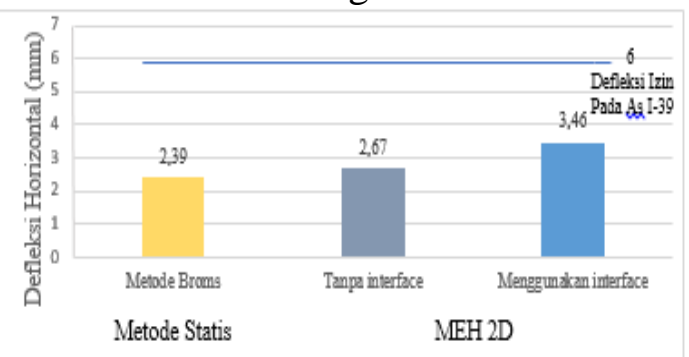

Gambar 2.11Perbandingan defleksi pondasi bored pile tunggal As I - 39 antara metode Broms dan metode elemen hingga 2D

Berdasarkan hasil Tabel 3.6 dapat disajikan secara grafik hasil analisa defleksi pondasi bored pile tunggal pada As C - 26 dapat dilihat pada Gambar 2.12 sebagai berikut :

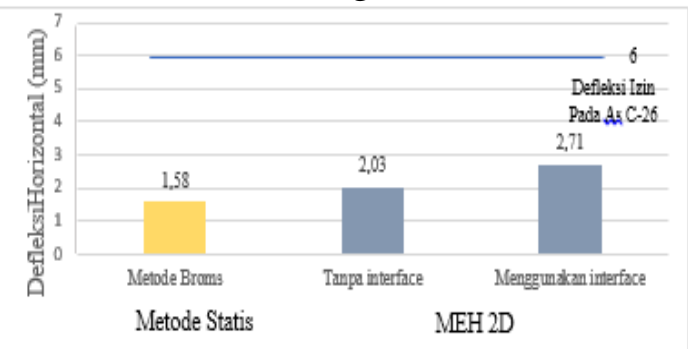

Gambar 2.12 Perbandingan defleksi pondasi bored pile tunggal As $\mathrm{C}-26$ antara metode Broms dan metode elemen hingga 2D
3.7 Hasil Analisa Penurunan Pondasi Bored Pile Tunggal

Tabel 3.7 Penurunan pondasi bored pile tunggal

\begin{tabular}{|c|c|c|c|}
\hline \multirow{2}{*}{$\begin{array}{c}\text { Titik } \\
\text { Pondasi }\end{array}$} & $\begin{array}{c}\text { Metode } \\
\text { Statis } \\
(\mathrm{mm})\end{array}$ & \multicolumn{2}{|c|}{$\begin{array}{c}\text { MEH 2D } \\
(\mathrm{mm})\end{array}$} \\
\cline { 2 - 4 } & $\begin{array}{c}\text { Dee Beer } \\
\& \text { Marten }\end{array}$ & $\begin{array}{c}\text { Tanpa } \\
\text { interface }\end{array}$ & $\begin{array}{c}\text { Dengan } \\
\text { interface }\end{array}$ \\
\hline As I-39 & 9,78 & 29,87 & 36,40 \\
\hline As C-26 & 8,44 & 23,46 & 29,07 \\
\hline
\end{tabular}

Berdasarkan hasil Tabel 3.7 dapat disajikan secara grafik hasil analisa penurunan pondasi bored pile tunggal pada As I - 39 dapat dilihat pada Gambar 2.13 sebagai berikut :

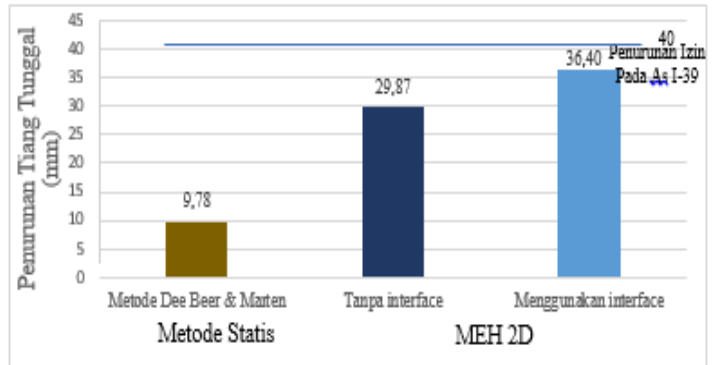

Gambar 2.13 Perbandingan penurunan pondasi bored pile tunggal As I - 39 antara metode Dee Beer \& Marten dan metode elemen hingga $2 \mathrm{D}$

Berdasarkan hasil Tabel 3.7 dapat disajikan secara grafik hasil analisa penurunan pondasi bored pile tunggal pada As C - 26 dapat dilihat pada Gambar 2.14 sebagai berikut :

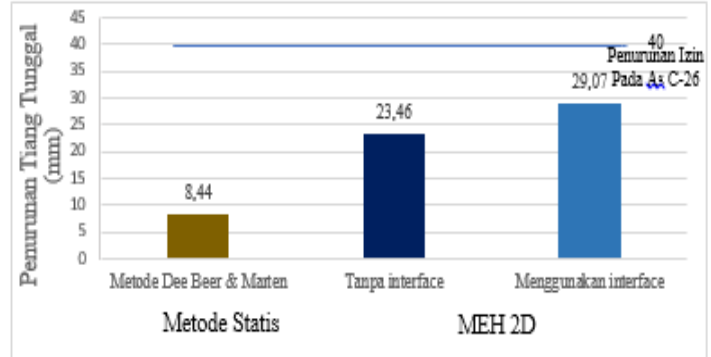

Gambar 2.14 Perbandingan penurunan pondasi bored pile tunggal As C - 26 antara metode Dee Beer \& Marten dan metode elemen hingga $2 \mathrm{D}$ 
Tinjauan kapasitas Dukung Pondasi Bored Pile Menggunakan Formula Statis Dan Elemen Hingga 2D Pada Gedung E Fakultas Teknik Universitas Islam Riau

3.8 Hasil Analisa Penurunan Pondasi Bored Pile Kelompok (Group)

Tabel 3.8 Penurunan pondasi bored pile kelompok (group)

\begin{tabular}{|c|c|c|c|}
\hline \multirow{2}{*}{$\begin{array}{c}\text { Titik } \\
\text { Pondasi }\end{array}$} & $\begin{array}{c}\text { Metode } \\
\text { Statis } \\
(\mathrm{mm})\end{array}$ & \multicolumn{2}{|c|}{$\begin{array}{c}\text { MEH 2D } \\
(\mathrm{mm})\end{array}$} \\
\cline { 2 - 4 } & $\begin{array}{c}\text { Metode } \\
\text { Vesic }\end{array}$ & $\begin{array}{c}\text { Tanpa } \\
\text { interface }\end{array}$ & $\begin{array}{c}\text { Dengan } \\
\text { interface }\end{array}$ \\
\hline As I-39 & 21,87 & 16,09 & 16,78 \\
\hline As C-26 & 18,87 & 9,95 & 10,38 \\
\hline
\end{tabular}

Berdasarkan hasil Tabel 3.8 dapat disajikan secara grafik hasil analisa penurunan pondasi bored pile kelompok (group) pada As I - 39 dapat dilihat pada Gambar 2.15 sebagai berikut :

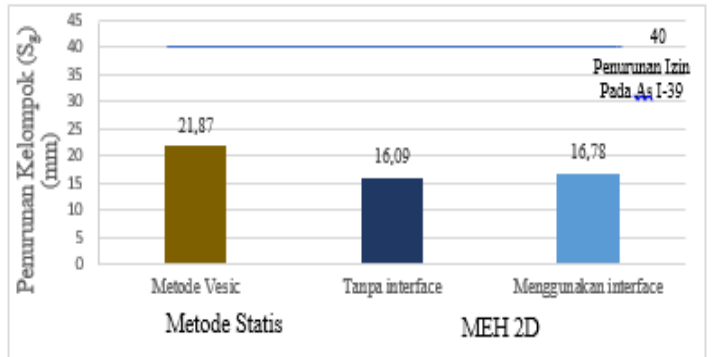

Gambar 2.15 Perbandingan penurunan pondasi bored pile kelompok (group) As I 39 antara metode Vesic dan Metode elemen hingga 2D

Berdasarkan hasil Tabel 3.8 dapat disajikan secara grafik hasil analisa penurunan pondasi bored pile kelompok (group) pada As C - 26 dapat dilihat pada Gambar 2.16 sebagai berikut

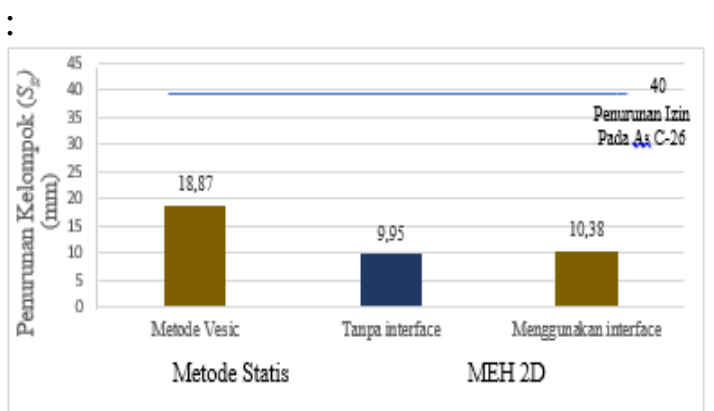

Gambar 2.16 Perbandingan penurunan pondasi bored pile kelompok (group) As C

- 26 antara metode Vesic dan Metode elemen hingga $2 \mathrm{D}$
3.8 Analisa Tegangan Geser Efektif Tanah Pondasi Bored Pile Tunggal

Tabel 3.9 Penurunan pondasi bored pile kelompok (group)

\begin{tabular}{|c|c|c|c|}
\hline \multirow{2}{*}{$\begin{array}{c}\text { Titik } \\
\text { Pondasi }\end{array}$} & \multicolumn{2}{|c|}{$\begin{array}{c}\tau_{\mathrm{xy}} \\
\left(\mathrm{kN} / \mathrm{m}^{2}\right)\end{array}$} & \multirow{2}{*}{$\begin{array}{c}\tau_{\mathrm{d}}^{6}{ }^{2} \\
\left(\mathrm{kN} / \mathrm{m}^{2}\right)\end{array}$} \\
\hline & $\begin{array}{c}\text { Tanpa } \\
\text { interface }\end{array}$ & $\begin{array}{l}\text { Dengan } \\
\text { interface }\end{array}$ & \\
\hline As I-39 & 631,01 & 1100 & 80,11 \\
\hline As C-26 & 504,25 & 903,53 & 80,11 \\
\hline
\end{tabular}

Berdasarkan hasil Tabel 3.9 dapat disajikan secara grafik hasil analisa tegangan efektif tanah pada pondasi bored pile tunggalpada As I - 39 dan As C - 26 dapat dilihat pada Gambar 2.17 sebagai berikut :

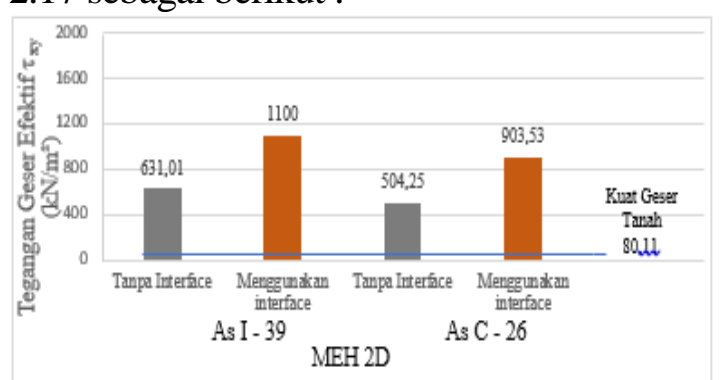

Gambar 2.17 Grafik tegangan geser efektif tanah pondasi bored pile As I - 39 dan C - 26 dengan metode elemen hingga $2 \mathrm{D}$

\section{KESIMPULAN DAN SARAN 4.1 Kesimpulan}

Berdasarkan hasil analisa dalam bab hasil dan pembahasan dari penelitian Tinjauan Kapasitas Dukung Pondasi Bored Pile Menggunakan Formula Statis Dan Elemen Hingga 2D Pada Gedung E Fakultas Teknik Universitas Islam Riau didapat beberapa kesimpulan sebagai berikut :

1. Berdasarkan hasil analisa kapasitas dukung $\left(Q_{\text {gall }}\right)$ bored pile As I-39 dan As C-26 pada titik S-1 dalam persentase nilai terbesar menggunakan formula statis diantaranya metode Aoki \& Alancer sebesar 39\%, dapat dinyatakan pondasi tidak aman terhadap beban yang bekerja pada pile cap, dengan metode Schmertmann \& Nottingham sebesar 128\%, metode Begemaan sebesar 
$139 \%$, dan metode elemen hingga 2D sebesar $169 \%$, dan kapasitas beban lateral tunggal $\left(H_{a}\right)$ dengan metode Broms sebesar $167 \%$ dan elemen hingga 2D sebesar 105\% maka dapat disimpulkan bahwa pondasi bored pile pada Gedung E Fakulatas Teknik Universitas Islam Riau tersebut aman terhadap beban yang bekerja pada pile cap.

2. Penurunan pondasi bored pile pada Gedung E Fakultas Teknik Universitas Islam Riau sudah aman terhadap penurunan dan defleksi yang dizinkan. Dimana penurunan dan defleksi pondasi bored pile As I-39 dan As C-26 dari nilai terbesar untuk tiang tunggal dengan metode Dee Beer \& Marten sebesar 9,78 mm dan metode elemen hingga 2D sebesar 36,40 $\mathrm{mm}$. Dan tiang kelompok (group) dengan metode Vesic sebesar sebesar 21,87 mm dan metode elemen hingga 2D sebesar $16,78 \mathrm{~mm}$. Defleksi pondasi bored pile terbesar dengan metode Broms 2,39 mm dan metode elemen hingga 2D sebesar 3,46 $\mathrm{mm}$.

3. Tegangan geser efektif tanah pondasi bored pile tunggal dari nilai terbesar dengan metode elemen hingga 2D tanpa interface sebesar $631,01 \mathrm{kN} / \mathrm{m}^{2}$ dan menggunakan interface $1100 \mathrm{kN} / \mathrm{m}^{2}$, maka dapat dinyatakan tegangan geser efektif tanah tidak memenuhi syarat yang diizinkan.

\subsection{Saran}

Dalam penulisan tugas akhir ini, beberapa saran yang dapat penulis sampaikan antara lain

1. Untuk penelitian selanjutnya analisa kapasitas dukung pondasi bored pile menggunakan metode Meyerhof, 1976.

2. Bagi penelitian selanjutnya menentukan beban yang bekerja pada pile cap menggunakan pembebanan gedung dan gempa dengan SNI yang terbaru.

3. Untuk peneltian selanjutnya dapat melakukan analisa kapasitas dukung menggunakan metode elemen hingga 3D agar didapatkan hasil sesuai kondisi sebenarnya.

\section{DAFTAR PUSTAKA}

Badan Standarisasi Nasional, 2002, Tata Cara Perhitungan Struktur Beton Untuk Bangunan Gedung SNI 032847-2002, Bandung.

Badan Standarisasi Nasional, 2002, Standar Perencanaan Ketahanan Gempa Untuk Struktur Bangunan Gedung SNI-1726-2002, Bandung.

Das, Braja., M, 1985. Mekanika Tanah Jilid 1. Erlangga. Jakarta.

Darma, Surya., 2015, Analasis Daya Dukung Pondasi Bored Pie Tunggal Diameter $100 \mathrm{~cm}$ Pada Proyek Pembangunan Hotel Grandika, Medan Tugas Akhir, Jurusan Teknik Sipil Fakultas Teknik Universitas Sumatera Utara, Medan.

Departemen Pekerjaan Umum, 1987, Pedoman Perencanaan Pembebanan Untuk Rumah Dan Gedung, Jakarta.

Deny, 2015, Analisa Kapasitas Dukung Pondasi Bored Pile Pada Gedung Mahasiswa Universitas Islam Riau, Tugas Akhir, Program Studi Teknik Sipil Fakultas Teknik Universitas Islam Riau, Pekanbaru.

Fadliansyah, 2011, Analisa Daya Dukung Pondasi Bored Pile Pada Proyek Pembangunan Hotel Santika Jalan Pengadilan Medan, Tugas Akhir, Program Pendidikan Eksrension Jurusan Teknik Sipil Fakultas Teknik Universitas Sumatera Utara, Medan.

Girsang, Priscilia., 2009, Analisa Daya Dukung Pondasi Bored Pile Tunggal Pada Proyek Pembangunan Gedung Crystal Square Jl. Imam Bonjol No. 6 Medan, Tugas Akhir, Jurusan Teknik Sipil Fakultas Teknik Universitas Sumatera Utara, Medan.

Ginting, E.Santaria., 2014, Analisa Daya Dukung Pondasi Bored Pile Dengan Metode Elemen Hingga Pada Proyek Fly Over Jamin Ginting Medan, Tugas Akhir, Bidang Studi Geoteknik Departemen Teknik Sipil Fakultas Teknik, Universitas Sumatera Utara, Medan. 
Hardiyatmo, H.C., 2002. Teknik Pondasi I, Edisi Kedua, Jurusan Teknik Sipil Universitas Gadjah Mada, Yogyakarta.

Hardiyatmo, H.C., 2008. Teknik Pondasi II, Jurusan Teknik Sipil Universitas Gadjah Mada, Yogyakarta.

Hulu, Henry.B, 2015, Analisa Daya Dukung Pondasi Bored Pile Dengan Menggunakan Metode Analitis (Studi Kasus Proyek Manhattan Mall Dan Condominium, Tugas Akhir, Bidang Studi Geoteknik Departermen Teknik Sipil Fakultas Teknik Universitas Sumatera Utara, Medan.

Toyeb, M., 2009, Perbandingan Kuat Dukung Pondasi Tiang Pancang Antara Beberapa Formula Statik Dan Dinamik Dengan Hasil PDA Tes Pada Pembangunan Gedung Rusunawa UIR, Tugas Akhir, Program Studi Teknik Sipil Fakultas Teknik Universitas Islam Riau, Pekanbaru.

Wesley, Laurence D. 2012. Mekanika Tanah. Andi. Yogyakarta.

Wihardi, M., 2015, Analisa Daya Dukung Pondasi Bored Pile Diameter 0,8 m Menggunakan Metode Analitis Dan Metode Elemen Hingga Pada Proyek Pembangunan Hotel Sapadia Medan, Tugas Akhir, Bidang Studi Geoteknik Departemen Teknik Sipil Fakultas Teknik, Universitas Sumatera Utara, Medan.

Widya, P.,B dan Leon, D, 2011, Stabilitas Tebing Pada Proyek Jalan Tol Semarang - Ungaran STA 6+000 Sampai 6+250, Tugas Akhir, Jurusan Teknik Sipil Fakultas Teknik, Universitas Diponegoro, Semarang.

Zulfahmi, 2015, Perencanaan Ulang Pondasi Bored Pile Pada Bangunan Bowling Center Kawasan Riau Town Square Berdasarkan Data SPT, Tugas Akhir, Program Studi Teknik Sipil Fakultas Teknik Universitas Islam Riau, Pekanbaru.

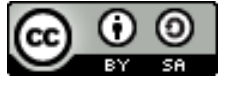

This is an open access article which means that all content is freely available without charge to the user or his/her institution. Jurnal Saintis allows the author(s) to hold the copyright without restriction. The copyright in the text of individual articles (including research articles, opinion articles, and abstracts) is the property of their respective authors distributed under the terms of the Creative Commons Attribution-ShareAlike 4.0 International License(https://creativecommons.org/licenses/by-sa/4.0/) which permits unrestricted use, distribution, and reproduction in any medium. Users are allowed to read, download, copy, distribute, search, or link to full-text articles in this journal without asking by giving appropriate credit, provide a link to the license, and indicate if changes were made. 